largely inaccessible to the Greekless undergraduate: republication of such articles in revised form, with Greek translated, might be a useful exercise.) Of the sixteen articles reprinted, three are drawn from J. Ober and C. Hedrick (edd.), Demokratia (Princeton, 1996), and two further from the co-editor of that book, Josiah Ober. However, the modern study of Athenian democracy owes a good deal to the schools of thought surrounding Ober, so it is perhaps fitting that such a 'reader' should reflect this.

As a sourcebook and reader, this book works well: it is clearly signposted and is a sound introduction to ancient democracy. It will introduce students to a wide range of ancient sources, and to scholarly argumentation and evaluation of the ancient sources as performed by some anglophone scholars in the last thirteen years of the twentieth century. However, it provides little by way of historical perspective on the secondary material. Perhaps teachers might direct their students to P. J. Rhodes's Ancient Democracy and Modern Ideology (London, 2003) as a commentary on the scholarship included in and excluded from this reader.

Trinity College, Dublin

PETER LIDDEL

\title{
DEMOCRACY AND US
}

\section{P. J. Rhodes: Ancient Democracy and Modern Ideology. Pp. 142. London: Duckworth, 2003. Paper, £10.99. ISBN: 0-7156-3220-5.}

This book is part of a new Duckworth series of 'polemical, revisionist or exploratory' essays which aim to 'provoke debate and controversy both within and beyond Classics'. R.'s volume fulfills this mandate, for he identifies and criticizes a number of trends in ancient historical scholarship, especially in the study of Athenian democracy, in ways that will likely incite the ire of some (not least one or two scholars targeted in the book) and the approval of others. R. is not usually a bomb-thrower; he is known rather for his erudite work in such important volumes as The Athenian Boule, A Commentary on the Aristotelian Athenaion Politeia and The Decrees of the Greek States. He succeeds here as well, however, for in this short book (really an extended essay, with less than ninety pages of text) he presents a credible argument about how one should - and should not—study ancient Athenian history, doing so without the bluster or excessive rancor that sometimes plagues efforts of this kind.

In his preface, R. summarizes the theses of the book, that 'In recent decades studies of ancient history overtly linked to an agenda in today's world have become respectable, as in the late nineteenth and early twentieth centuries they were not' (p. 7), and that 'although total objectivity and disengagement are not and never have been possible, scholars who aspire to objectivity and disengagement are likely to do better history, and also to be more useful to our own world, than those who rejoice in their subjectivity and in their engagement with our world' (p. 8). The first chapter ('History') briefly considers the nature of history, discussing such issues as 'facts', objectivity, subjectivity, and metahistory. The issues are dealt with generally, with references to particular historians or approaches mostly left to the footnotes. R. insists that, within the great variety of worthwhile perspectives and approaches that one can bring to history, one must acknowledge that history is about real people and actual events from the past which cannot be altered by the historian. The next chapter ('Democracy') provides a few pages on the history of ancient (primarily Athenian) democracy; while one might quibble over this or that detail within the presentation (e.g. on the date of demokratia's appearance in Greece or Athens), it is fundamentally sound and succeeds

The Classical Review vol. 54 no. 2 @ The Classical Association 2004; all rights reserved 
in providing background on the subject for non-classicists. Chapter 3 ('Democracy: Good or Bad?') surveys opinions of democracy as expressed from the late medieval period to the mid-nineteenth century, ending with Grote, who championed the positive example ancient Athens could present for modern polities. Grote provides a graceful transition to the fourth chapter ('Democracy: Fashions in Scholarship'), which considers views scholars have taken from Grote forward. The sketches in both Chapters 3 and 4 are extremely brief, but this allows for a synoptic view and a quick and easy read over what could otherwise be tedious ground. One wonders at times, however, what R. himself thinks about the material he rather mechanically presents here. Chapter 5, while also ending without a conclusion, appears clearer in purpose: 'Athenian Democracy and Us' focuses, with a disapproving air, on recent, mostly American efforts to connect ancient democracy to modern times. Among other things, R. notes the pressure on presses and academics to make even serious scholarly publications 'accessible' to ill-prepared students, and the frequent scholarly attempts to highlight the utility of studying ancient democratic practices in order to reconsider modern ones.

R. saves the lion's share of opinion for the last chapter, 'How to Study Athenian Democracy'. Here he juxtaposes his own views of how history should be done with those of other scholars. Josiah Ober's stated positions figure prominently: Ober is criticized not for his focus on ancient ideology (which R. rightly considers complementary to M. H. Hansen's and R.'s own institutional approach), but for showing 'wishful thinking' in interpreting the Cleisthenic reforms of 508/7 and for a dubious inclination to draw modern lessons from ancient history. R. also attacks the tendency of some to infer an overly broad rôle for demokratia in Athenian drama, religion, and other cultural realms. V. D. Hanson, among others, draws fire for the sometimes simplistic use of classical history to teach moral and political lessons.

The case R. makes overall, when considered with the qualifications he carefully appends along the way, is persuasive. I have long believed, for example, that it is largely irrelevant that one cannot attain absolute historical objectivity; the important thing is for historians to make the effort to remain objective in the face of their circumstances and biases. He also puts it well when he states that 'history is more useful when it does not try too self-consciously to be useful' (p. 90). Less satisfying is a phrase on which R. relies overmuch when criticizing other approaches: we must 'do justice' to the past events and people we study. It sounds reasonable, but what exactly does it mean?

Not all will agree with the theses of R.'s engaging little book, but it is thought-provoking and worthy of every classicist's attention.

Harvard University

ERIC ROBINSON

\section{ATHENIAN GREED}

R. K. B ацот: Greed and Injustice in Classical Athens. Pp. x +291. Princeton and Oxford: Princeton University Press, 2001. Cased, £27.95. ISBN: 0-691-04855-X.

This ambitious, wide-ranging and complex book aims not just at intellectual history but also at the social and political history of greed in Athens (pp. 1, 57). B. examines a range of vocabulary of greed (e.g. pleonexia, koros, philochrematia) that is specifically connected to the notion of injustice and that therefore fits into not only a moral but a political framework. As an umbrella definition, greed is defined as

The Classical Review vol. 54 no. 2 @ The Classical Association 2004; all rights reserved 